\title{
Population differentiation in Spartina patens: gas-exchange responses to salinity
}

\author{
S. R. Pezeshki \\ Laboratory for Wetland Soils and Sediments, Center for Wetland Resources, Louisiana State University, Baton Rouge, \\ Louisiana 70803, USA
}

\begin{abstract}
Greenhouse and laboratory studies were conducted to evaluate the effects of gradual vs sudden increase in salinity from 5 to $25 \mathrm{ppt}$ on leaf conductance and net carbon assimilation of 2 Spartina patens populations (Ferblanc and Clovelly) from USA Gulf Coast marshes. Results indicated that the 2 populations had quite similar gas-exchange responses to salinity treatments. However, with progression of each experiment, some differences in responses became apparent. The Ferblanc population (which grows under high salinities in a brackish-saltmarsh zone) maintained greater net carbon assimilation than did the Clovelly population (which grows under low salinities of a freshbrackish zone) in 5 and $15 \mathrm{ppt}$ salinity treatment. At $25 \mathrm{ppt}$ salinity, net carbon assimilation was reduced by $10 \%$ for Ferblanc, which was not statistically significant $(p=0.05)$, and by $22 \%$ for Clovelly population, which was statistically significant $(\mathrm{p} \leq 0.05)$. In addition, Ferblanc plants produced significantly $(p \leq 0.05)$ greater leaf area than did the Clovelly population. The observed responses are in accord with the habitat characteristics where these populations grow naturally. Results indicate a potential differentiation between the 2 populations under the salinity-flooding combinations tested. However, there is no evidence of restricted gene flow between these populations. Thus differences found may be due to differential survival of offsprings from a common gene pool rather than evolutionary divergence of isolated populations.
\end{abstract}

\section{INTRODUCTION}

Spartina patens (Ait) Muhl. is a dominant brackish marsh species found in a wide range of flooding and salinity conditions in USA Gulf Coast marshes. Although $S$. patens is a salt-tolerant species, it is not an obligate halophyte; consequently its growth is adversely affected by salinity (Parrondo et al. 1978, Gosselink 1984). This response has been partially attributed to the adverse effects of salinity on gas exchange of this species. For example, when soil salinity was increased from 0 to 22 ppt, stomatal conductance and net photosynthesis were reduced 54 and $43 \%$, respectively (Pezeshki et al. 1987).

Field observations on the US Gulf Coast suggest considerable variations in performance of various populations of this species in response to flooding and salinity, suggesting potential differences in the effects of salinity increase on leaf conductance and net carbon assimilation of these populations. However, to date no studies have been conducted to evaluate the responses of these populations to changes in flooding and salinity regimes. Evaluation of gas-exchange characteristics in populations evolved under different soil-salinity conditions would provide basic data needed for understand- ing photosynthetic behavior and provide a basis for comparative evaluation of threshold salinities which trigger photosynthetic inhibition among populations from various areas.

The main objective of this study was to evaluate the potential population differentiation in response to salinity changes resulting from differences in tidal regimes, and those changes' effects on gas-exchange parameters, in plants of 2 Spartina patens populations which occur naturally under contrasting salinity regimes. It was hypothesized that (1) populations evolved under severe salinity regimes possess advantageous gasexchange characteristics, and (2) a gas-exchange measurement approach could be used as a screening technique for evaluation of potential population differentiation. Gas-exchange techniques have been used previously as screening methods for evaluation of population differentiation in other marsh grasses (Bowman 1987). Greenhouse and laboratory studies were conducted to evaluate responses to gradual increase in salinity and to sudden exposure to salinity, respectively. In both studies, the 'common garden' approach was used by evaluating populations together under uniform conditions (Waddington 1953, Goodman 1973). 


\section{MATERIALS AND METHODS}

Samples of 2 Spartina patens populations (Ferblanc and Clovelly) were collected along a transect extending from the edge of a freshwater to a saltmarsh habitat ca $30 \mathrm{~km}$ apart. The Ferblanc population grows near the higher-salinity, brackish-saltmarsh interface zone $\left(29^{\circ} 15^{\prime} \mathrm{N}, 90^{\circ} 5^{\prime} \mathrm{W}\right)$; the Clovelly population grows in the northern edge of where $S$. patens grows which is near the freshwater-brackish interface zone $\left(29^{\circ} 30^{\prime} \mathrm{N}\right.$, $90^{\circ} 10^{\prime} \mathrm{W}$ ). Tillers (60 to 80 population $^{-1}$ ) were collected, transferred to a greenhouse and cloned. Newly germinated culms and associated roots were planted in nursery pots filled with commercial potting soil. Study pots were watered with freshwater to excess and fertilized with a commercial water-soluble plant food (2319-17, N-P-K respective percentages) once per week. Two week after the transplanting, salinity treatments were initiated. Salt solutions were prepared using Instant Ocean Synthetic Sea Salt (Aquarium Systems, Inc., Mentor, Ohio, USA), with major ionic components of $47 \% \mathrm{Cl}, 26 \% \mathrm{Na}, 6 \% \mathrm{SO}_{4}, 3 \% \mathrm{Mg}, 1 \% \mathrm{Ca}$ and $1 \%$ $\mathrm{K}$ (percentage of dry weight).

Greenhouse study. Gradual exposure to salinity began by flooding the pots with 1 ppt $\left(17 \mathrm{~mol} \mathrm{~m}^{-3}\right)$ salt on the first day. The salinity level for Treatment $1\left(\mathrm{~T}_{1}\right)$ was then increased to 3 ppt on Day 3 and to 5 ppt on Day 7 of the experiment. The second treatment $\left(T_{2}\right)$ consisted of salinity increases similar to those of $T_{1}$ Days 1 through 7 , and salinity was increased to $10 \mathrm{ppt}$ on Day 8 and to 15 ppt on Day 10. In the third treatment $\left(T_{3}\right)$, plants were subjected to salinity levels as in $T_{2}$ except that salinity was increased to 20 ppt on Day 12 and 25 ppt on Day 15. The salinity treatments chosen represent the range of salinity encountered by these populations. The predominant salinity for the Clovelly population is ca $5 \mathrm{ppt}$, while the Ferblanc population grows at ca $10 \mathrm{ppt}$ salinity. The highest salinity was tested to allow evaluation of both populations under elevated salinity. A YSI model 33 meter (Yellow Springs Instrument Co., Yellow Springs, Ohio, USA) was used for measurements of salt concentrations in all pots throughout the experiment. In addition, throughout the study, pots were drained weekly and freshly made salt solution at respective concentrations and plant food were added to the pots.

To monitor changes in oxidation-reduction processes in the soil, soil redox potential (Eh) was measured using a pH Controller Model 5997 (Horizon Ecology Co., Chicago, Illinois, USA), calomel electrode probes, and platinum electrodes. Eh was measured daily after allowing the electrodes to equilibrate in place for $12 \mathrm{~h}$. Corrections were made as described by Patrick \& DeLaune $(1972,1977)$. Eh measurements were made on 12 platinum electrodes per population ( 1 per pot).
The probes were installed $5 \mathrm{~cm}$ below the soil surface and were rotated among different pots.

The experiment consisted of a completely randomized block design with 2 populations, 3 salinity treatments and 54 replicates (pots) per treatment. Each pot consisted of 1 plantlet which subsequently reproduced new culms within the pot.

Diurnal measurements of air temperature, relative humidity, photosynthetic photon flux density (PPFD), leaf temperature, leaf conductance $\left(g_{\mathrm{w}}\right)$ and net carbon assimilation (A) were made on 5 sample leaves treatment $^{-1}$ population ${ }^{-1}$ every $3 \mathrm{~h}$ from 8:00 to 18:00 h on each sample day. There were 15 sample days during the experiment (Days 8, 12, 16, 22, 24, 28, 31, 34, 36, 37, $41,43,45,47,491$.

Leaf conductance was measured using a steady-state porometer (LI-1600, LiCor, Inc., Lincoln, Nebraska, USA). After recording $g_{w}$, the same leaf was used for measurement of $A$, which was performed rapidly using a portable gas-exchange system (Model A120, ADC, Field Analytical System, P.K. Morgan Inst. Co., Dallas, Texas, USA). The system was composed of 3 components: (1) an ADC Parkinson Leaf Chamber; (2) an infrared $\mathrm{CO}_{2}$ analyzer, ADC Model LCA-2; and (3) an air-supply unit controlling humidity and flow of incoming air. The leaf was enclosed in the chamber and PPFD and differential $\mathrm{CO}_{2}$ levels were recorded. Mature, well-developed leaves were used for all measurements. Net carbon assimilation rates were calculated from the flow rate of air through the chamber and from the $\mathrm{CO}_{2}$ partial pressure differences between incoming and outgoing air, as outlined by Caemmerer \& Farquhar (1981). Both $g_{\mathrm{w}}$ and $A$ were calculated per unit leaf area (single surface), determined with a surface-area meter (Model SI701, SKYE Instrument, Inc., Buckingham, Pennsylvania, USA). Water-use efficiency (WUE) was calculated from the ratio of $\mathrm{CO}_{2}$ assimilated per amount of $\mathrm{H}_{2} \mathrm{O}$ transpired per kiloPascal vapor pressure deficit, a measure of $\mathrm{CO}_{2}$ fixed per unit of leaf conductance (Rawson \& Woodard 1976).

The General Linear Models procedure of the SAS System (SAS Institute, Inc., Cary, North Carolina, USA) was used to test for differences in $g_{w}$ and $A$ among treatment means, by applying a repeated-measures design which included the day and hour of measurement (Moser et al. 1990).

Laboratory experiment. Uniform plants of both populations (12 plants population ${ }^{-1}$ ) were transferred to pots $30 \mathrm{~cm}$ deep and $25 \mathrm{~cm}$ in diameter in the laboratory and were kept in a growth chamber under a cycle of $14 \mathrm{~h}$ light $\left(25^{\circ} \mathrm{C}, 70 \%\right.$ relative humidity $)$ and $10 \mathrm{~h}$ dark $\left(20^{\circ} \mathrm{C}, 85 \%\right.$ relative humidity). Plants were randomly assigned to 3 treatments $(4$ plants treatment $^{-1}$ population $\left.{ }^{-1}\right)$. Salt solutions were prepared as described above at 3 concentrations: 5, 15 and 25 ppt. 
Treatment was initiated by flooding pots with saltwater, containing the respective salinity concentrations for a given treatment, in 1 application (sudden exposure). During the experiment, pots were drained weekly and freshly made salt solution at the respective salinity level was added to each pot.

Repeated measures of $g_{w}$ and $A$ were made twice per day, at 3 and $6 \mathrm{~h}$ into the light period, from Day 1 to Day 28. These measurements were conducted on 4 attached leaves ( 1 leaf plant ${ }^{-1}$ ) treatment ${ }^{-1}$ population $^{-1}$ at each measurement period.

\section{RESULTS}

\section{Greenhouse study}

Soil Eh averaged $250 \pm 22 \mathrm{mV}$ in all treatments, which indicates redox levels below the point of oxygen disappearance (DeLaune et al. 1990). Leaf conductance (Fig. 1) was not affected but net carbon assimilation (Fig. 2) in both populations decreased as salinity concentration increased during the greenhouse study. In the Ferblanc population there was no reduction in $g_{w}$ and $A$ in response to salinity increases to $15 \mathrm{ppt}$, compared to

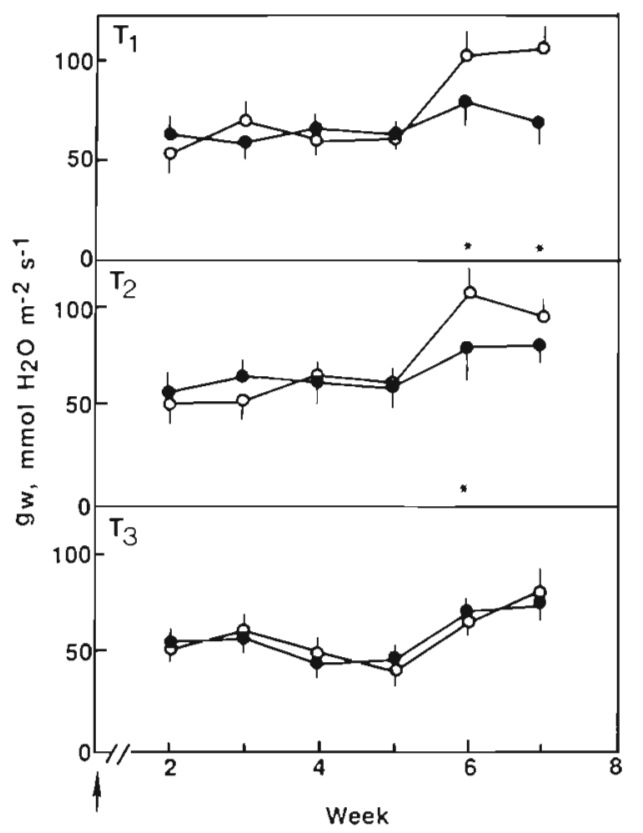

Fig. 1. Spartina patens. Leaf conductance $\left(g_{\mathrm{w}}\right)$ responses of 2 populations (10) Ferblanc; (•) Clovelly] to $\left(\mathrm{T}_{1}\right) 5 \mathrm{ppt},\left(\mathrm{T}_{2}\right) 15$ ppt and $\left(T_{3}\right) 25 \mathrm{ppt}$ salinity. The experiment was conducted under greenhouse conditions; plants were exposed to the 3 treatments by gradual addition of salt to floodwater over a 2 wk period, followed by 7 wk of measurements. Arrow signifies treatment initiation; bars represent SE. (") Denotes significant difference $(p \leq 0.05)$ between populations in the designated period

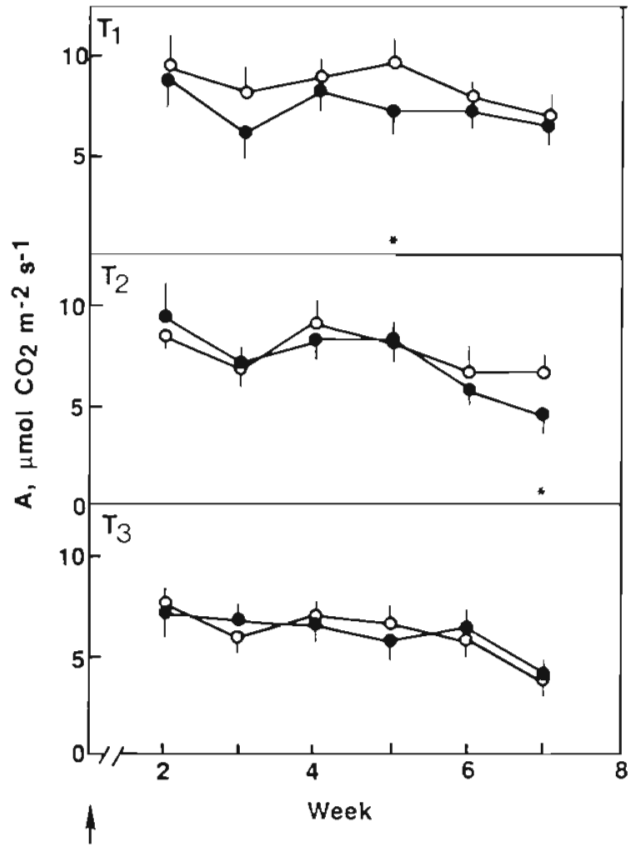

Fig. 2. Spartina patens. Net carbon assimilation $(A)$ response of 2 populations to $\left(T_{1}\right) 5 \mathrm{ppt},\left(\mathrm{T}_{2}\right) 15 \mathrm{ppt}$, and $\left(\mathrm{T}_{3}\right) 25 \mathrm{ppt}$ salinity. Treatments and symbols as in Fig. 1

those values at $5 \mathrm{ppt}$. Over the same range of salinity changes, the Clovelly population had no reduction in $g_{w}$ but displayed a $10 \%$ reduction in $A$ (significant, p $\leq$ 0.05 ). At $25 \mathrm{ppt}$ salinity, $g_{\mathrm{w}}$ and $A$ were reduced further in both populations, as compared to those values at lower salinities. In the Ferblanc population, $g_{w}$ decreased by

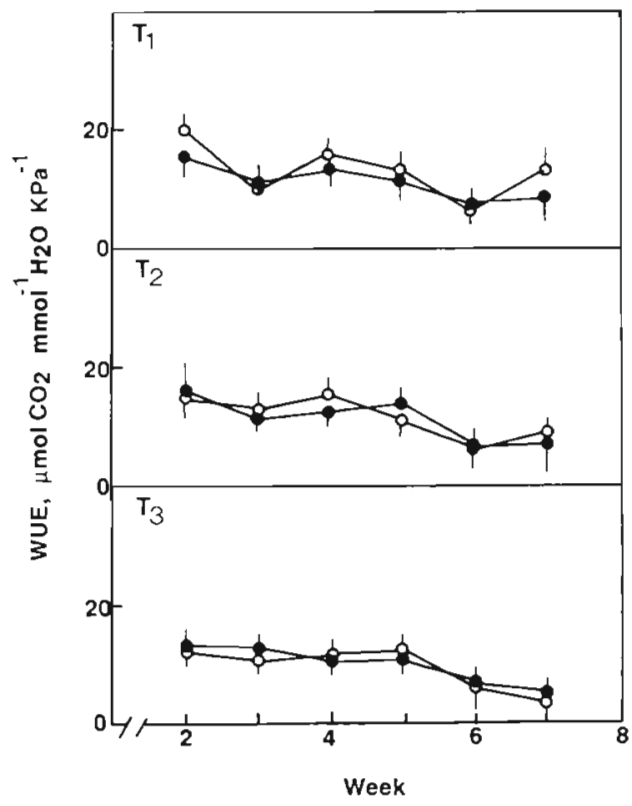

Fig. 3. Spartina patens. Water-use efficiency (WUE, $\mu \mathrm{mol} \mathrm{CO}_{2}$ $\mathrm{mmol}^{-1} \mathrm{H}_{2} \mathrm{O} \mathrm{kPa}^{-1}$ vapor pressure deficit) response of 2 populations to $\left(\mathrm{T}_{1}\right) 5 \mathrm{ppt},\left(\mathrm{T}_{2}\right) 15 \mathrm{ppt}$, and $\left(\mathrm{T}_{3}\right) 25 \mathrm{ppt}$ salinity. Treatments and symbols as in Fig. 1 
$14 \%$ and $A$ by $10 \%$ at $25 \mathrm{ppt}$, relative to those values at 5 ppt. Over the same range of salinity changes, $g_{w}$ was reduced by $24 \%$ and $A$ by $22 \%$ in the Clovelly population. Statistical analysis showed that reduction in $g_{\mathrm{w}}$ was not significant $(\mathrm{p}=0.05)$ in both populations between salinities of 5 and $15 \mathrm{ppt}$ but was significant at $25 \mathrm{ppt}$. Net carbon assimilation rates were not significantly affected in the Ferblanc population but were significantly reduced in the Clovelly at 25 ppt salinity ( $\mathrm{p} \leq 0.05$ ).

Generally, the Ferblanc population exhibited greater $g_{w}$ under the 5 and 15 ppt treatments during Weeks 6 and 7 as compared to the Clovelly population, a statistically significant difference ( $p \leq 0.05$ ). The Ferblanc population also had slightly (but not significantly) greater $A$ values at 5 and 15 ppt salinities as compared to the Clovelly population. However, for the $25 \mathrm{ppt}$ treatment, both populations displayed comparable $g_{\mathrm{w}}$ and $A$ values (Figs. 1 \& 2). WUE was reduced in both populations as salinity increased. However, both populations exhibited comparable WUE at various salinity treatments (Fig. 3).

Time-course changes in leaf area for both populations showed different responses (Fig. 4). In both populations, leaf area was significantly reduced in response to increased salinity ( $p \leq 0.05$ ). However, the Ferblanc population maintained greater leaf area under 5 and 15 ppt compared to the Clovelly population. Greater leaf areas coupled with higher net photosynthesis in the Ferblanc population compared to the Clovelly population

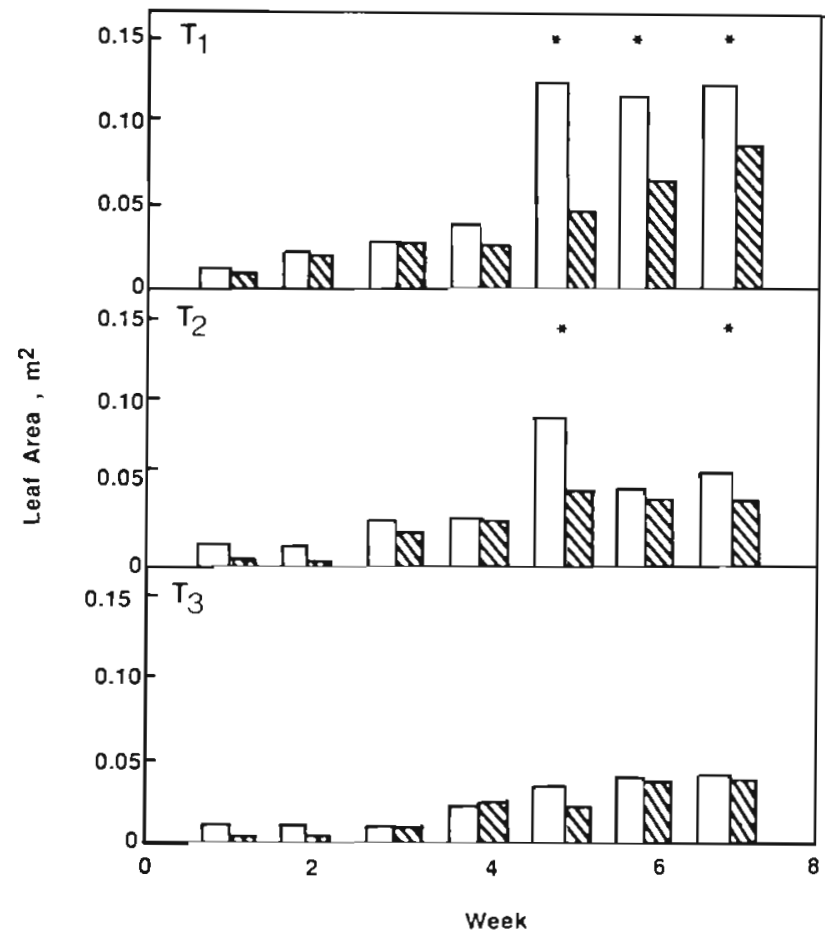

Fig. 4. Spartina patens. Leaf area $\left(\mathrm{m}^{2}\right.$ leaf area per pot $)$ response of 2 populations to $\left(\mathrm{T}_{1}\right) 5 \mathrm{ppt},\left(\mathrm{T}_{2}\right) 15 \mathrm{ppt}$, and $\left(\mathrm{T}_{3}\right) 25$ ppt salinity. Treatments and symbols as in Fig. 1

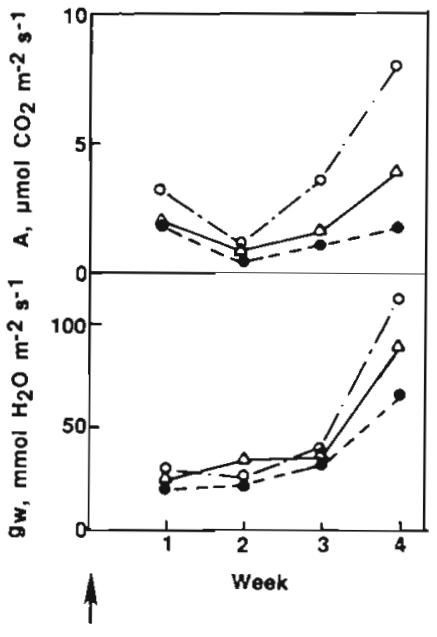

Fig. 5. Spartina patens. Leaf conductance $\left(g_{w}\right)$ and net carbon assimilation $(A)$ in the Ferblanc population following sudden exposure to floodwater salinity concentration of (0) 5 ppt, $(\Delta)$ $15 \mathrm{ppt}$, and ( $25 \mathrm{ppt}$ salinity. The experiment was conducted under controlled environment conditions $\left(25^{\circ} \mathrm{C}, 70 \%\right.$ relative humidity, photosynthetic photon flux density $\approx 1000 \mu \mathrm{mol} \mathrm{m} \mathrm{m}^{-2}$ $\mathrm{s}^{-1}$ ). Arrow indicates treatment initiation. Each point represents 56 measurements conducted during each measurement period; bars represent SE. (") Denotes significant difference $(p \leq 0.05)$ among treatments in the designated period

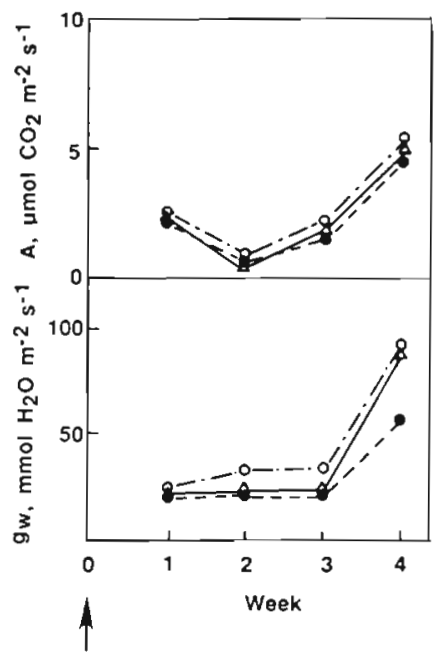

Fig. 6. Spartina patens. Leaf conductance $\left(g_{w}\right)$ and net carbon assimilation $(A)$ in the Clovelly population following sudden exposure to floodwater salinity concentration of (o) $5 \mathrm{ppt}$, (s) 15 ppt, and $(\bullet) 25$ ppt salinty. Conditions and symbols as in Fig. 5

increases the potential for carbon fixation and growth of this population under low to moderate salinity levels.

\section{Laboratory experiment}

Sudden exposure of both populations to saltwater flooding resulted in reduction in $g_{w}$ during the first $3 \mathrm{wk}$ 
(Figs. $5 \& 6$ ). There was a difference in response patterns of $g_{w}$ and $A$ between the 2 populations. There was a greater difference in $g_{w}$ and $A$ among various treatments within the Ferblanc population compared to the Clovelly population. Initial reductions in $g_{\mathrm{w}}$ and $A$ were followed by a substantial recovery during Week 4 in both populations. In the Ferblanc population, $g_{w}$ recovery rates in plants at 5 and 15 ppt salinity were faster than in plants at $25 \mathrm{ppt}$. Recovery of $A$ was noted in the Ferblanc population beginning at Week 3 , which was closely associated with initial salinity treatment i.e. plants in the $5 \mathrm{ppt}$ salinity treatment displayed greater recovery rates than those at 15 and $25 \mathrm{ppt}$ (Fig. $5)$. In the Clovelly population, a similar $g_{w}$ recovery pattern was found; however, $A$ recovery did not follow a similar pattern (Fig. 6). Significant reduction in $A(p \leq$ 0.05 ) was found in both populations when subjected to sudden exposure to saltwater containing salinities of 15 and $25 \mathrm{ppt}$, as compared to plants under the $5 \mathrm{ppt}$ treatment (Fig. 7).

\section{DISCUSSION}

Increases in salt concentrations in the rhizosphere coupled with soil anaerobiosis resulted in reduction of leaf conductance and net photosynthesis in both populations of Spartina patens. Similar responses to salinity have been previously documented for $S$. patens (Pezeshki et al. 1987). Stomatal closure in response to salinity has been reported for several species (Downton 1977, Kemp \& Cunningham 1981, Longstreth et al. 1984, Pearcy \& Ustin 1984). The decrease in $A$ found in response to salinity may be attributed both to stomatal control (Downton 1977, Longstreth \& Strain 1977) and to non-stomatal (metabolic) factors (Longstreth \&

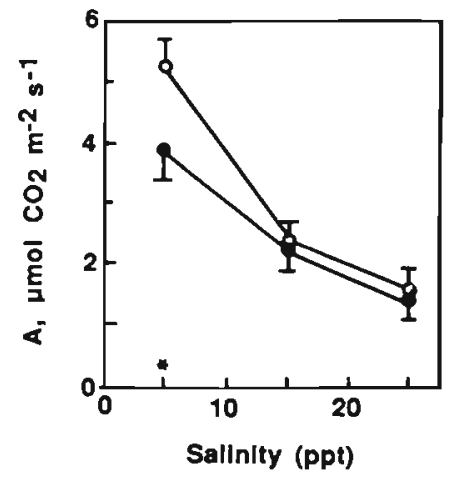

Fig. 7. Spartina patens. Net carbon assimilation [(o) Ferblanc; (•) Clovelly population] following sudden exposure to saltwater treatments in a controlled laboratory experiment. Each point is the mean for the respective population (per treatment) throughout the $28 \mathrm{~d}$ of the experiment. Experimental conditions as in Fig. 5; bars represent SE
Nobel 1979, Walker et al. 1982, Longstreth et al. 1984). Pearcy \& Ustin (1984) found reductions in A rates in Spartina and Scirpus species as a result of diffusional limitations and metabolic effects when soil salinity increased. Longstreth et al. (1984) reported $51 \%$ reduction in $A$ for Alternanthera philoxerides plants after salt application. In the present study, recovery trends were noted for $A$ after initial reductions, indicating some photosynthetic acclimation/adaptation to salinity conditions in both populations, but recovery appeared to be more pronounced in Ferblanc population (cf. Figs. $5 \& 6$ ).

Soil anaerobiosis and salinity are major environmental factors which influence plant distribution and growth in coastal marshes (Nestler 1977. DeLaune et al. 1983). Although Spartina patens is considered a salttolerant species, its growth is adversely affected by salinity (Parrondo et al. 1978, Gosselink 1984). The present data indicate that the physiological performances of the 2 populations in response to salinity treatments were quite similar. However, plants from the Ferblanc population (which grows under high salinity) produced significantly greater leaf area ( $\mathrm{p} \leq 0.05$ ) under low and moderate salinities than did the Clovelly population (which occurs in a less saline environment). Similar responses have been reported for Juncus roemerianus by Eleuterius (1989).

The apparent differentation between the 2 Spartina patens populations is evidenced by (1) examination of variations in $\mathrm{CO}_{2}$ uptake under different salinity regimes, particularly under the low-salinity treatment, and (2) leaf-area development, the latter being significantly different between the 2 populations. The primary environmental factor to which such differentiation may be attributed is sediment-water salinity, which creates a substantial selection pressure for plants.

Population differentiation in marsh grasses has been a topic of considerable interest to plant ecophysiologists and geneticists. The existence of height forms in Spartina alterniflora in saltmarshes of the US Atlantic and Gulf Coast (Nestler 1977, DeLaune et al. 1983) and population differentiation in S. patens (Silander 1985) and S. foliosa (Cain \& Harvey 1983) has prompted numerous research efforts aimed at determining whether these populations were genetically distinct (ecotypes) or homogeneous (ecophenes). Population differentiation may provide one means of coping with environmental heterogeneity (Heslop-Harrison 1964 , Ehrlich \& Raven 1969). Such differentiation has been reported for many marsh grasses (Boorman 1967, Gray \& Scott 1980, Jefferies et al. 1981, Huiskes et al. 1985, Eleuterius 1989). Silander (1985) reported that genotypes of $S$. patens from adjacent saltmarsh, swale and dune areas showed evidence of genetic differentiation. Through the evolutionary process under the selection 
pressure of a distinct habitat, a homogeneous species can gradually evolve into diverse specialized populations. As a result, these populations become distinct genetically (Eleuterius 1989). In the present study, there was no evidence of restricted gene flow between the $2 S$. patens populations studied. Thus, it is difficult to distinguish between evolutionary divergence of isolated' populations and site-specific differential survival of offspring from a common gene pool. In addition, only 1 environmental factor, i.e. salinity, was evaluated in the presence of waterlogging. However, physiological responses are closely related to the interaction of several environmental factors. The observed responses of the 2 populations to salinity and flooding could be explained in light of field observations which indicate that the Ferblanc population is associated with sediments containing high salinities characteristic of a brackish-saltmarsh zone. The Clovelly population, on the other hand, occupies the less saline environment of freshwater-brackish zones characteristic of these marshes. Future research should evaluate the potential for genetic differentation among various populations of $S$. patens in the US Gulf Coast and examine the success of reciprocal transplantation among the populations in high-salinity habitats under natural field conditions.

Acknowledgements. Funding for this research was provided from Louisiana Education quality Support Fund Project No. LEQSF (1987-90)-RD-7. The author is thankful to 4 anonymous reviewers for critical review of this manuscript.

\section{LITERATURE CITED}

Boorman, L. A. (1967). Biological flora of the British Isles. Limonium vulgare. J. Ecol. 55: 221-232

Bowman, W. D. (1987). Effect of salinity on leaf gas exchange in two populations of a $\mathrm{C}_{4}$ nonhalophyte. Pl. Physiol. 85: $1055-1058$

Caemmerer, S. von, Farquhar, G. D. (1981). Some relationships between the biochemistry of photosynthesis and the gas exchange of leaves. Planta 153: 376-387

DeLaune, R. D., Pezeshki, S. R., Pardue, J. H. (1990). An oxidation-reduction buffer for evaluating physiological response of plants to root oxygen stress. Envir. exp. Bot. 30: $243-247$

DeLaune, R. D., Smith, C. J., Patrick, W. H. Jr. (1983). Relationship of marsh elevation, redox potential and sulfide to Spartina alterniflora productivity. Soil Sci. Soc. Am. J. 47: 390-395

Downton, W. J. S. (1977). Influence of rootstocks on the accumulation of chloride, sodium and potassium in grapevines. Aust. J. agric. Res. 28: 879-889

Ehrlich, P. R., Raven, P. H. (1969). Differentiation of populations. Science 615: 1228-1232

Eleuterius, L. N. (1989). Natural selection and genetic adaptation to hypersalinity in Juncus roemerianus. Aquat. Bot. 36: $45-53$

This article was submitted to the editor
Goodman, P. J. (1973). Physiological and ecotypic adaptations of plants to salt desert conditions in Utah. J. Ecol. 61: $473-494$

Gosselink, J. G. (1984). The ecology of Delta marshes of coastal Louisiana: a community profile. Fish \& Wildlife Service, U. S. Department of the Interior, Publ. \#FWS/ OBS-84/09. US. Dept. Interior, Washington, D.C.

Gray, A. J., Scott, R. (1980). A genecological study of Puccinellia maritima. I. Variation estimated from single plant samples from British populations. New Phytol. 85: 89-107

Heslop-Harrison, J. (1964). Forty years of genecology. In: Cragg, J. B. (ed.) Advances in ecological research, Vol. 2. Academic Press, New York, p. 159-247

Huiskes, A. H. L., Soelen, J. van, Markusse, M. M. (1985). Field studies on the variability of populations of Aster trifolium in relation to salt-marsh zonation. Vegetatio 61: 163-169

Jefferies, R. L., Davy, A. J., Rudmik, T. (1981). Population biology of the saltmarsh annual Salicornia europaea. J. Ecol. 69: 17-31

Kemp, P. R., Cunningham, G. L. (1981). Light, temperature and salinity effects on growth, leaf anatomy and photosynthesis of Distichlis spicata. Am. J. Bot. 68: 507-516

Longstreth, D. J., Bolanos, J. A., Smith, J. E. (1984). Salinity effects on photosynthesis and growth in Alternanthera philoxeroides. Pl. Physiol. 75: 1044-1047

Longstreth, D. J., Nobel, P. S. (1979). Salinity effects on leaf anatomy. Consequences for photosynthesis. Pl. Physiol. 63: 700-703

Longstreth, D. J., Strain, B. R. (1977). Effects of salinity and illumination on photosynthesis of Spartina alterniflora. Oecologia 31: 191-199

Moser, E. B., Saxton, A. M., Pezeshki, S. R. (1990). Repeated measures analysis of vaniance: application to tree research. Can. J. Forest Res. 20:524-535

Nestler, J. (1977). Interstitial salinity as a cause of ecophenic variation in Spartina alterniflora. Estuar. coast. mar. Sci. 5 $707-714$

Parrondo, R. T., Gosselink, J. G., Hopkinson, C. S. (1978). Effects of salinity and drainage on the growth of three saltmarsh grasses. Bot. Gaz. 139: 102-107

Patrick, W. H. Jr., DeLaune, R. D. (1972). Characterization of the oxidized and reduced zones in flooded soils. Soil. Soc. Am. Proc. 36: 573-576

Patrick, W. H. Jr, DeLaune, R. D. (1977). Chemical and biological redox systems affecting nutrient availability in the coastal wetlands. Geosci. Man. 18: 131-137

Pearcy, R. W., Ustin, S. L. (1984). Effects of salinity on growth and photosynthesis of three California tidal marsh species. Oecologia 62: 68-73

Pezeshki, S. R., DeLaune, R. D., Patrick, W. H. Jr (1987). Response of Spartina patens to increasing levels of salinity in rapidly subsiding marshes of the Mississippi River Deltaic plain. Estuar. coast. Shelf Sci. 221: 389-399

Rawson, H. M., Woodard, R. G. (1976). Photosynthesis and transpiration in dicotyledonous plants. I. Expanding leaves of tobacco and sunflower. Aust. J. Pl. Physiol. 3: 247-256

Silander, J. A. (1985). The genetic basis of the ecological amplitude of Spartina patens. II. Variance and correlation analysis. Evolution 39: 1034-1052

Waddington, C. H. (1953). Genetic assimilation of an aquired character. Evolution 7: 118-126

Walker, R. R., Torofalvy, E., Downton, W. J. (1982). Photosynthetic responses of citrus varieties, Rangepur lime and Etrog citron to salt treatments. Aust. J. Pl. Physiol. 9: 783-790

Manuscript first received: July 10, 1990

Revised version accepted: March 11, 1991 